\title{
新規化合物探索のための電子論計算に基づく $\mathrm{AB}$ 二元系 化合物の安定性評価之四元系金属間化合物への拡張
}

\section{三浦 誠 司* 滝沢＼cjkstart聡大久保賢二＼cjkstart毛利哲 雄}

\author{
北海道大学大学院工学研究科材料科学専攻
}

J. Japan Inst. Metals, Vol. 71, No. 10 (2007), pp. 860-868

Special Issue on Emergent Researches for Substitution to and Effective Usage of Rare and Scarce Metals (C) 2007 The Japan Institute of Metals

\section{An Approach for a Broad Search of New Compound Using the First Principles Calculation; AB Type Binary and Quaternary Intermetallic-Alloy}

\author{
Seiji Miura*, Satoshi Takizawa, Kenji Ohkubo and Tetsuo Mohri \\ Division of Materials Science and Engineering, Graduate School of Engineering, Hokkaido University, Sapporo 060-8628
}

\begin{abstract}
In order to search stable intermetallic compounds in a broad composition area in ternary, quaternary and higher-order systems, it is effective to utilize the calculation of formation enthalpy for screening prior to the experimental study. As the number of candidates is tremendously large for ternary and quaternary alloys, an augmented-spherical-wave (ASW) method was employed for fast calculation. To evaluate the accuracy of the calculation, the formation enthalpy of B2, $\mathrm{L} 1_{0}$ and B19 structures of 99 equi-atomic compounds are estimated, and the most stable structure for each alloy is compared with the literature. It is found that $75 \%$ of the reported structures are predicted by the calculation results, and B19 structure tends to be evaluated less stable than $\mathrm{L}_{0}$ structure. The formation enthalpy of Heusler-like structure with $\mathrm{Co}-\mathrm{Fe}-\mathrm{Ti}-\mathrm{Zr}$ equi-atomic quaternary composition is also estimated and this quaternary compound is unstable comparing with the estimated formation enthalpy of binary B2-CoFe, CoZr, FeTi and FeZr. An experimental study revealed there is a phase near the composition of the quaternary compound, but the structure is Laves- ${ }_{1} 14 \mathrm{Fe}_{2} \mathrm{Zr}$, neither the Heusler type nor bcc-based structure. It is concluded that the combination of ASW calculation and the experimental study is suitable for a broad search of compounds with relatively symmetric structure.
\end{abstract}

(Received May 1, 2007; Accepted August 10, 2007)

Keywords: intermetallic compounds, quaternary phase diagram, augmented-spherical-wave (ASW)

\section{1. 緒言}

金属間化合物には形状記憶合金や水素吸蔵合金など特異な 機械的・機能的性質を発現するものが多数存在するが，これ ら機能は構成要素である複数の元素が規則的に配列している ことに大きく依拠している，一般に，金属間化合物の機能向 上やコスト低減・安定供給などを目的として，構成要素以外 の元素を添加する. Fig. 1 に例として, $\mathrm{L} 1_{2}$ 型金属間化合物 $\mathrm{Ni}_{3} \mathrm{Al}$ に対する種々の金属元素の置換挙動を示す 1 . 等 $\mathrm{Ni}$ 線 に沿った固溶領域を示す元素は $\mathrm{Al}$-site に, 等 $\mathrm{Al}$ 線に沿っ た固溶領域を示す元素は Ni-site に置換する傾向があること を意味するが，元素によって最大固溶量に大きな差があるこ とがわかる. $\mathrm{Si}, \mathrm{Ga}, \mathrm{Ge}$ などの $\mathrm{Ni}$ と $\mathrm{L}_{2}$ 型金属間化合物を 形成する元素以外では，一般には規則配列を支配する原子間 相互作用の違いから物性の変化や相安定性低下が生じるとさ れる. 複数の結晶構造間の相安定性, すなわち生成エンタル ピーの差は例えば形状記憶合金では変態温度， $\mathrm{L} 1_{2}$ 型金属間

\footnotetext{
* Corresponding author, E-mail: miura@eng.hokudai.ac.jp
}

化合物では強さの正の温度依存性の程度を支配する要因であ ることから, 添加元素によって相の安定性を変化させ, 物性 をコントロールする取り組みはこれまで個別の化合物におい て精力的に行われてきた2).しかし，これまでに行われてき た研究は $\mathrm{A}-\mathrm{B}$ 二元系に存在する化合物 $\mathrm{A}_{\mathrm{x}} \mathrm{B}_{\mathrm{y}}$ の一方に置換

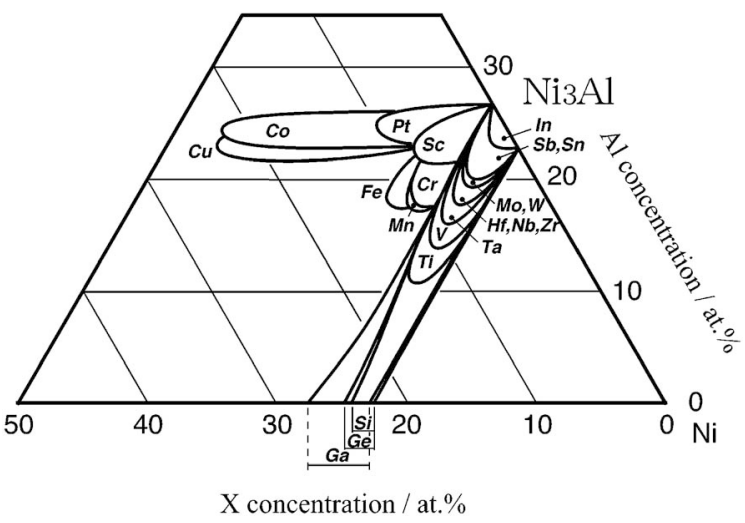

Fig. 1 Semi-schematic depiction of the solubility lobes of ternary $\mathrm{Ni}_{3} \mathrm{Al}$ phase for various elements redrawn from [1]. 
する元素 C を導入する，三元系への拡張が主であった．

これに対し, 構成元素が全く異なりながら同じ結晶構造を 持つ金属間化合物の間で連続固溶体を形成する例が知られて いる. $\mathrm{L}_{2}$ 型化合物である $\mathrm{Ni}_{3} \mathrm{Al}$ と $\mathrm{Co}_{3} \mathrm{Ti}$ を例にとる. Fig. 1 に示すように $\mathrm{Ni}_{3} \mathrm{Al}$ に Co や $\mathrm{Ti}$ を単独に添加してもその固 溶量には限界があるが，Fig. 2(a)に示すようにCo と Ti の 比を $3: 1$ として添加すると $\left(\mathrm{Ni}_{\mathrm{X}}, \mathrm{Co}_{1-\mathrm{X}}\right)_{3}\left(\mathrm{Al}_{\mathrm{X}}, \mathrm{Ti}_{1-\mathrm{X}}\right)$ で記 述できる $\mathrm{Ni}_{3} \mathrm{Al}$ から $\mathrm{Co}_{3} \mathrm{Ti}$ に至る任意の組成の $\mathrm{L} 1_{2}$ 型化合 物が得られ ${ }^{3)}$ ，単結晶合金の機械的性質が両者を兼ね備えた 魅力的なものであることが報告されている4)。一方で，Fig. 2 (b) に示すように $\mathrm{L}_{2}$ 型化合物である $\mathrm{Ni}_{3} \mathrm{Si}$ と $\mathrm{Co}_{3} \mathrm{Ti}$ では 連続固溶体を形成しないことが報告されている5)。このよう に，複数の添加元素の選択抢よび添加量調整を行うことによ って相の安定性維持が可能であるが，その支配因子は必ずし も明確ではなく，拡張性に難がある。さらに近年，Sato ら によって報告された $\mathrm{L}_{2}-\mathrm{Co}_{3}(\mathrm{Al}, \mathrm{W})^{6)}$ のように，三元系状 態図中央付近に孤立して見出される化合物を実験的に探索す ることは容易なことではない。

第三期科学技術基本計画における材料分野の重要なテーマ として，「希少資源・不足資源代替並びに効率的利用技術」 が揭げられている： $\mathrm{L}_{0}-\mathrm{FePt}$ などの磁性合金 ${ }^{7)}$ や白金属系 高温形状記憶合金 ${ }^{8}$ など，希少な元素を必須とする化合物は 多数存在する. 化合物の持ついくつかの性質が結晶構造に依 存する場合，これを損なわずに豊富な元素で置換すること や，さらに多種多様な元素を組み合わせた多元系化合物への 展開，未探索の組成領域に新たな化合物を見出すなどが今後 さらに重要となっていくが，上述のように実験的手法でのみ のアプローチは困難である．そのため化合物の安定性評価か ら探索を行うことが試みられてきた.

Hume-Rothery は化合物の安定性を定性的に支配する要 因を提案した ${ }^{9)}$ 。この考えに基づき，相安定性を議論する上 で原子サイズや電子一原子比 $(e / a)$ などのパラメータを用いた 合金化学的手法が多用されてきた ${ }^{2)}$. 例えば， $\mathrm{Ni}$ 基超合金で
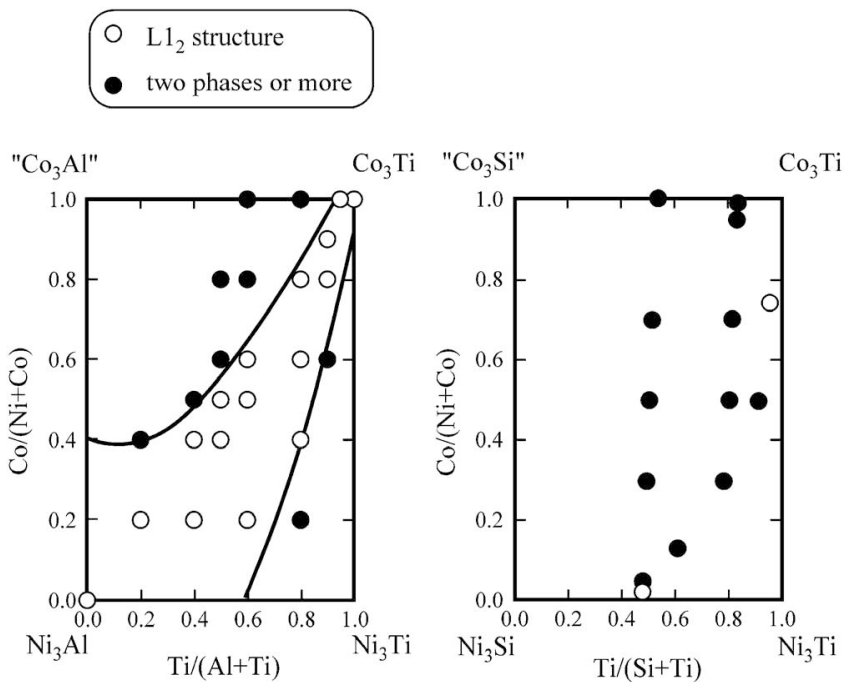

Fig. 2 Semi-schematic depiction of the solubility lobes of $\mathrm{L} 1_{2}$ phase for (a) $\mathrm{Ni}-\mathrm{Al}-\mathrm{Co}_{0}-\mathrm{Ti}$ system redrawn from [3], and (b) $\mathrm{Ni}-\mathrm{Si}-\mathrm{Co}_{0}-\mathrm{Ti}$ system redrawn from $[5]$.
は $\mathrm{Nv}$ 值が機械的性質の劣化につながるラーベス相形成の予 測に用いられ，さらに電子論計算に基づき決定した Md 值, Bo 值の利用へと展開されてきた ${ }^{10)}$ 。これに対し，電子論計 算(第一原理計算)は実験的に求嫨倠い同一組成の種々の構造 の生成エンタルピー算出を通じて状態図の高精度予測に用い られるほか11), フェルミレベル近傍の電子状態を求めて熱 電特性などの物性予測や理解に用いられるなど, 高い精度で の計算が可能となってきた。この手法は近年の計算機資源の 高速化・低価格化 · 大容量化によって大きな進展を遂げつつ あるが，実験に対する指針として必要なアウトプットの精度 やそれに必要な時間・投資などの資源投入と実験への資源投 入の最適なバランスが見積もりがたい点が，いまだにこれら 手法の実験的な合金開発への利用が限定的である理由と思わ れる.

状態図に抢ける安定相の確定に必要な計算は高い精度を求 められる，置換挙動を理解するためには非常に大きな unit cell が用いられるが12)，計算に必要な時間は膨大なものとな る. 多元系状態図中での化合物探索は，対象とする結晶構造 の複雑さ, 候補となる構造の多さからさらに計算が複雑にな り，このような高い精度での遂行の困難さが増す。さらに， このような課題は多数の元素の組み合わせを対象とすること になる。例を四元系合金 $\mathrm{A}-\mathrm{B}-\mathrm{C}-\mathrm{D}$ にとる。 $\mathrm{A}_{50} \mathrm{~B}_{50}$ や $\mathrm{C}_{50} \mathrm{D}_{50}$ などがある特定の構造を持つときに等比組成 $\left(\mathrm{A}_{25} \mathrm{~B}_{25} \mathrm{C}_{25} \mathrm{D}_{25}\right)$ の化合物が同様の構造を有するかどうかは, $\mathrm{A}_{50} \mathrm{~B}_{50}$ や $\mathrm{C}_{50} \mathrm{D}_{50}$ などと比較した安定性の評価が必要であ る.このような課題の対象となる組み合わせの総数は対象元 素が 50 種類としたとき，以下のようになる.

$$
{ }_{50} \mathrm{C}_{4}=\frac{50 \times 49 \times 48 \times 47}{1 \times 2 \times 3 \times 4}=230300
$$

このような数の合金すべてを実験的に探査することは，コン ビナトリアル的手法などを用いなければ不可能であり, 拡散 対を用いた状態図作製法 ${ }^{13)}$ や計算による「virtual laboratory $\rfloor^{14)}$ ，データマイニング的手法の確立と適用15,16) が提案されている。一方, 対象を特定の結晶構造を有する化 合物の存在に絞って化合物探査の前段階に電子論計算による 「ある程度」のスクリーニングを施すことが可能であれば， 効率的な探査が期待できる. 電子論計算と実験的手法の資源 投入のバランスは目的や精度によっても変化するが，このよ うな膨大な数の化合物探査に電子論計算を援用する場合は, 「可能な限り高い精度」を追求する以外に，「必要最低限の精 度」で可能な限り高速に計算を行うというストラテジーも選 択肢になりうる。これによって多数の化合物の安定性に対す る鳥瞰図的な視野が得られれば，化合物の置換可能組成域発 掘や新規化合物探索を通じた希少資源の節約に大きなアドバ ンテージを提供することとなる。ここで，計算誤差を考慮し つつ，ある一定以上の生成エンタルピーの大きさ，すなわち 不安定さを相の存在の判断に用いることが可能かどうかを明 らかにすることが必要である。相の出現は競合相の間での生 成エンタルピーによって決定されるが，すべての競合相に関 して電子論計算を行うことは，「可能な限り高い精度」を追 求するストラテジーと同様に多大な労力を必要とする。ここ での目的が「ある結晶構造を有する相の出現の有無」の判 
断，すなわちスクリーニングであることから，厳密性には欠 けるものの, 生成エンタルピーの大きさによる安定性評価の 可能性を見極めていく必要があると考えられる.

本研究では, 二元化合物の安定性と, それに対する添加元 素の効果 (置換挙動など)を理解するために必要な計算精度と 計算所要時間のバランスについての知見を得ることを目的と した，そのため，磁性体や熱電変換素子などで今後ますます 有用となってくるであろう $\mathrm{L}_{0}$ 型化合物やホイスラー型化 合物を対象とし, 電子論計算手法としては若干精度に劣るが 高速である augmented-spherical-wave (ASW) 法を採用し て，上記のような考え方を指針として計算科学的なアプロー チと実験的な実証を組み合わせた効率的探索法の可能性を明 らかにすることとした。そこで，1：1 AB 二元系化合物の $\mathrm{B} 2$ 構造, $\mathrm{L} 1_{0}$ 構造, B19 構造の生成エンタルピーを 99 組の 合金について求め, 文献に報告されている安定相・準安定相 との対応を比較した. さらに, ホイスラ一型化合物を仮定し て行った $1: 1: 1: 1$ 組成の四元合金の電子論計算と実験か ら，このような化合物探査法の可能性を検討することとした.

\section{2. 計 算 方 法}

原子の配列や結晶格子の異なる結晶構造間のエネルギー差 を評価するために, 密度汎関数法 ${ }^{17,18)}$ に基づく電子論計算を 行った．計算に用いたのは線形化されたバンド計算法の一つ である augmented-spherical-wave (ASW) 法19)である。こ の方法は電子の空間分布を球対称に仮定しているために結晶 格子が異方的な構造を持つような系の計算は精度の高い結果 を得られないが，波動関数を展開する基底関数が少なくて済 むために計算が高速であるという長所を持ち, 本研究の目的 に合致する。

交換・相関エネルギー項は Moruzzi らによって得られた パラメータを用い20)，周期律表第 6 周期の重い元素を扱え るように，スピンー軌道結合以外の相対論補正を取り入れ $た^{21)}$. 軌道角運動量が $1=3$ の部分波までを基底関数に取り 入れた。

1: 1 の組成比を持つ結晶構造として $\mathrm{B} 2$ 構造, $\mathrm{L} 1_{0}$ 構造, $\mathrm{B} 19$ 構造の三つを計算対象とし, $\mathrm{L} 1_{0}$ 構造と B19 構造に対 しては「理想的な」 $\mathrm{c} / \mathrm{a}$ 比を保ったまま，体積を変化させて 最もエネルギーの低い原子間距離を探した． $\mathrm{AB}$ 化合物の対

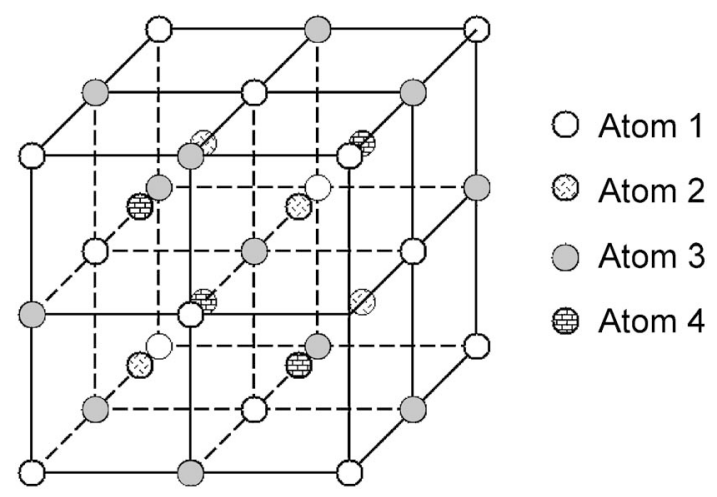

Fig. 3 Atomic arrangement of Heusler structure.
象元素には，A としてはメンデレーエフ数の順に Fe, Ru, Os, Co, Rh, Ir, Ni, Pt, Pd を，B としては Zr, Hf, Ti, Ta, Nb, $\mathrm{V}, \mathrm{W}, \mathrm{Mo}, \mathrm{Cr}, \mathrm{Re}, \mathrm{Mn}$ を採った. なおメンデレーエフ数は Pettforによって提案され22)，その後種々の変更の提案がな されているが15), ここでは Pettfor が提案した值を用いた. さらに，1:1:1:1の組成比を持つ合金に対しては結晶構 造として Fig. 3 に示すホイスラー構造に類似した unit cell を仮定し，対角線に沿った原子配列を(1) $\mathrm{Co}-\mathrm{Fe}-\mathrm{Ti}-\mathrm{Zr}$ ，(2) $\mathrm{Co}-\mathrm{Fe}-\mathrm{Zr}-\mathrm{Ti} ，(3) \mathrm{Co}-\mathrm{Zr}-\mathrm{Fe}-\mathrm{Ti}$ の三通りにとって，それら のエネルギーを求めた。

\section{3. 実 験 方 法}

本研究では $\mathrm{Co}_{\mathrm{C}} \mathrm{Fe}-\mathrm{Ti}-\mathrm{Zr}$ 四元系の $1: 1: 1: 1$ の組成比 を有する合金をモデルケースとして電子論計算によって生成 エンタルピーを求める. これと比較するため, いくつかの合 金を作製して本系に打ける $1: 1: 1: 1$ 組成近傍での安定相 についての知見を得ることとした．この四元系合金について は報告が見当たらず，その部分状態図である $\mathrm{Co}-\mathrm{Fe}-\mathrm{Ti}, \mathrm{Co}-$ $\mathrm{Fe}-\mathrm{Zr}, \mathrm{Co}-\mathrm{Ti}-\mathrm{Zr}$ 抢よび $\mathrm{Fe}-\mathrm{Ti}-\mathrm{Zr}$ の各三元系状態図も確定 しているとはいいがたい. 四つの元素から二つの元素を選ん で構成される二元化合物としては，B2 型構造を持つ CoFe, CoTi, CoZr, FeTi が知られている。一方, Ti-Zr 系は高温で はbcc 構造の，低温では hcp 構造の連続固溶体が形成さ れ，化合物は存在しない。また，Fe-Zr では $1: 1$ 組成の化 合物は報告されていない23)。CoTi-CoZr および CoTi-FeTi の間は全率固溶の B2 相領域が広がっていることが報告され ている24,25).

本研究では合金組成を $25 \mathrm{Co}-25 \mathrm{Fe}-25 \mathrm{Ti}-25 \mathrm{Zr}$ および $22 \mathrm{Co}-29 \mathrm{Fe}-23 \mathrm{Ti}-26 \mathrm{Zr}($ at \% ) とした. 今後これらを alloy1, alloy 2 と呼称する. 溶解原料としては電解コバルト (純度 99.9\%)，電解鉄 (純度 99.9\%) を用い, チタンおよびジルコ ニウムはスポンジチタン (純度 $99.7 \%$ ), スポンジジルコニ ウム (純度 $99.6 \%$ ) をアーク溶解後圧延した薄板を原料とし た. 合金質量は $10 \mathrm{~g}$ とし，アルゴンアーク溶解炉で数回溶 解の後, ファインカッターで切断, 石英管に真空封入して $900^{\circ} \mathrm{C}$ ，96 時間の均質加熱処理を施した。As-cast 材および 熱処理材は SEM-WDS (wavelength dispersive X-ray spectroscopy)による組織観察と相の組成分析, $\operatorname{XRD}(\mathrm{Cu}-\mathrm{K} \alpha, 30$ $\mathrm{kV}, 300 \mathrm{~mA})$ によって得た回折ピークから相の同定を試み た.

\section{4. 計算結果および考察}

計算結果例を Fig. 4 に示す。この図は生成エンタルピー の原子間距離依存性を示している. FeTi では B19 構造や $\mathrm{L} 1_{0}$ 構造に比べて B2 構造が安定であるという結果が得られ たのに対し, NiTi では $\mathrm{L} 1_{0}$ 構造と B19 構造の安定性が近く, B2 構造の安定性もそれほど低くないという結果となった. これらの計算結果は既に報告されている実験値および他の計 算手法による結果とは傾向の一致を見た。ここでは一例とし て B2-HfX(X: Co, Rh， Ru，Fe)の生成エンタルピーを， 

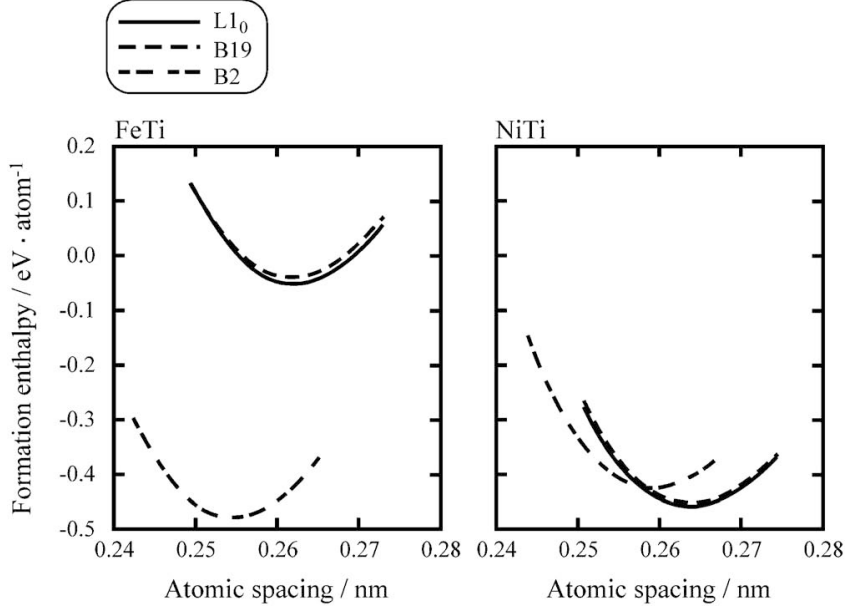

Fig. 4 Results of ASW calculations for (a) FeTi and (b) NiTi, respectively.

Table 1 Experimental and calculated enthalpy of formation of B2-HfX compounds. unit : $\mathrm{eV} /$ atom

\begin{tabular}{lccc}
\hline Compound & ASW & FLAPW & \\
\hline HfCo & -0.47 & -0.31 & -0.44 \\
\hline HfRh & -0.76 & -0.67 & -0.99 \\
\hline $\mathrm{HfRu}$ & -0.67 & -0.70 & -0.95 \\
\hline $\mathrm{HfFe}$ & -0.34 & -0.25 & - \\
\hline
\end{tabular}

Novakovic らが full-potential linearized augumented plane waves Calculation(FLAPW)によって求めた結果，および実 験的に求められた結果と合わせて Table 1 に示す26,27). ここ から, 本研究で行った ASW 法による計算結果は, 全体の傾 向を知るために相対的な安定性評価をする上では十分なもの と判断される.

$\mathrm{B} 2$ 構造および $\mathrm{L} 1_{0}$ 構造の単位胞体積の計算結果と文献 值 ${ }^{28)}$ の比較を Fig. 5 に示す. Mn を含む合金は偏差が大きい が，それ以外では計算結果のほうが格子定数で $3 \%$ 程度, 体 積で $10 \%$ 程度小さいものの, 図の対角線近くに分布し, 対 応関係は良好であるといえる，実験結果は常温での測定值で あることから，計算結果と比べて熱膨張による増加もあるも のと考えられる. 寺田らによって種々の B2 化合物の熱澎張 定数が系統的に調べられているが29), 概ね $10^{-5} \mathrm{~K}^{-1}$ 程度で あり，熱膨張の寄与は格子定数に対して $0.1 \%$ 程度となる. よって上記の差を説明するには不十分である. ASW 法に限 らず汎密度関数法に基づく計算は平衡格子定数を 2 ～3\%小 さく見積もる傾向があることが知られて抢り，本結果もそれ によるものと考えられる.

$\mathrm{L}_{0}$ 構造に関しては正方晶歪を考慮していないことが系統 的な偏差を生む可能性がある。そこで, Fig. 6 には, 文献 值 ${ }^{28)}$ から求めた単位胞体積 $\mathrm{V}_{0}$ と計算結果から求めた単位胞 体積 $\mathrm{V}$ の差を $d V / V=V_{0}-V / V$ によって評価し, 文献值か

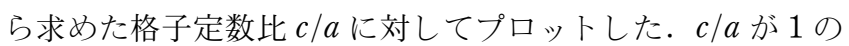
周辺では, $c / a$ が小さくなるにつれて偏差が大きくなる傾向 が認められる. Mn 合金では $c / a$ が小さくなる傾向があり, (a) B2

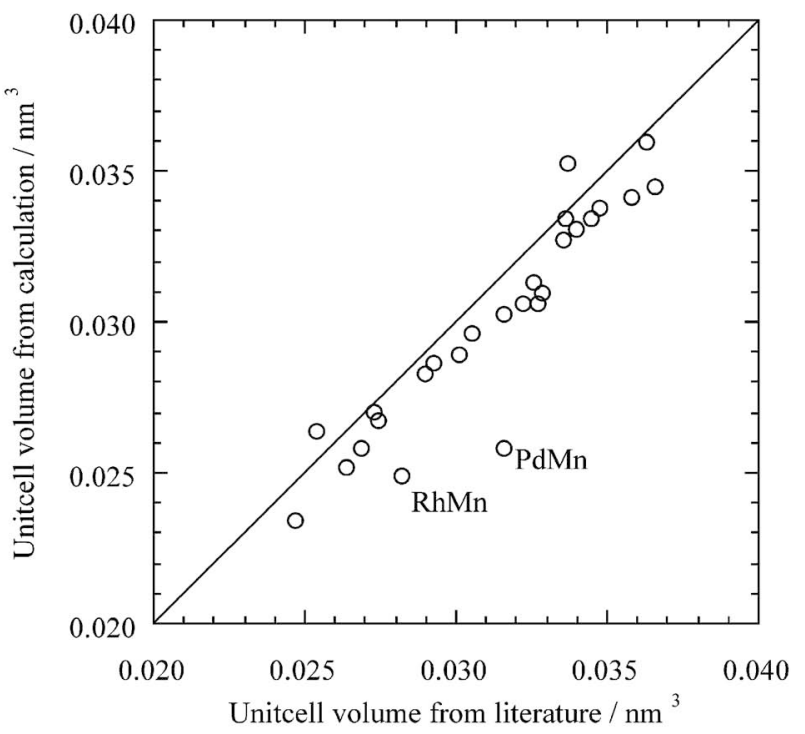

(b) $\mathrm{L}_{0}$

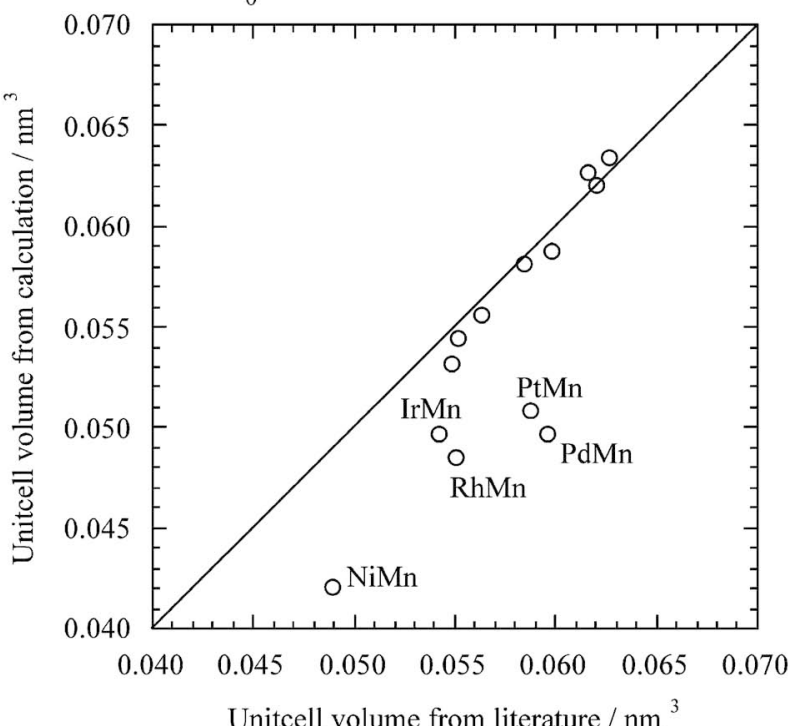

Fig. 5 Comparison of unitcell volume between the present results by calculation and data from literature 28). (a) B2 structure and (b) $\mathrm{L} 1_{0}$ structure.

これが計算で考慮されていないことが偏差の一因と考えられ る.

Fig. 7 には, ASW 法によって求めた各 AB 合金の結晶構 造間の生成エンタルピー差を示す。これに基づき, 各 $\mathrm{AB}$ 合 金の最も安定な構造を求め, 縦横にそれぞれ A, B 元素をメ ンデレーエフ数の順に配した Pettior map 上に示したものが Fig. 8(a)である.ここで,（）に示したものは三種類の構 造の中で最も安定であっても生成エンタルピーが正, すなわ ち不安定であることを示す。また, 網かけで示した PtHf は 三種類の構造間の生成エンタルピー差がごく小さかった。こ の結果と比較するため, 最近の二元系状態図集 ${ }^{23)}$ に基づい た Pettifor map を Fig. 8(b)に示す.ここで, 温度によって $\mathrm{B} 2$ 構造, $\mathrm{L} 1_{0}$ 構造, $\mathrm{B} 19$ 構造のうちから複数の結晶構造を とるものはそれらを記載してある.この領域内では, 左上に 


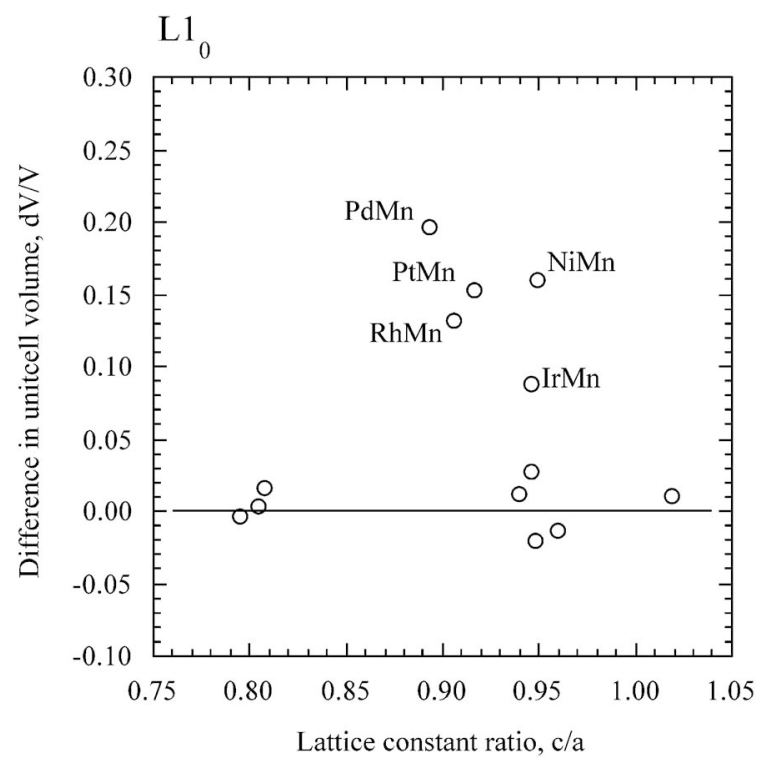

Fig. 6 Effect of the lattice constant ratio, c/a, on the deviation of the calculated unitcell volume.

(a) $\mathrm{L} 1_{0}-\mathrm{B} 2$

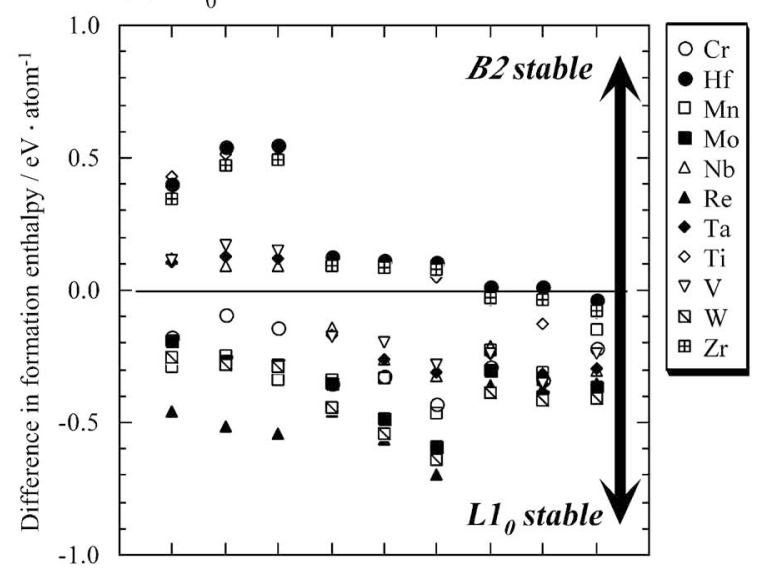

(b) B19-B2

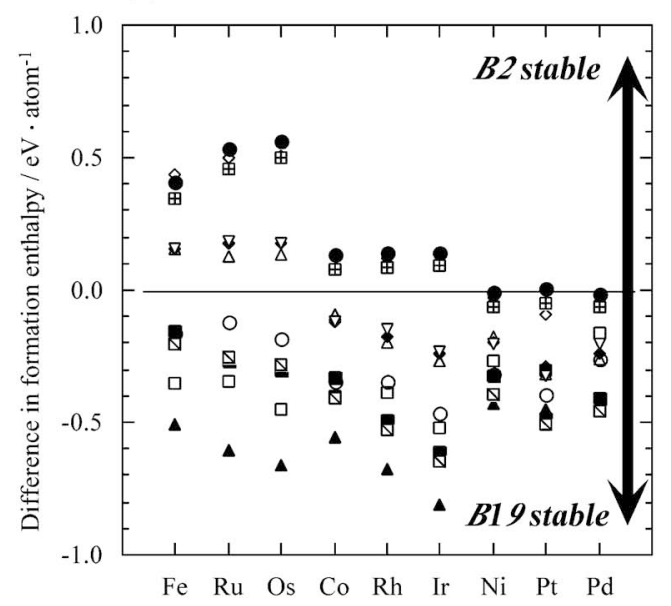

Fig. 7 Difference in the formation enthalpy between (a) $\mathrm{L}_{0}$ and B2 structures, and (b) B19 and B2 structures, respectively.
$\mathrm{B} 2$ 構造が集まり，右下に向かって順に $\mathrm{L} 1_{0}$ 構造， B 19 構造 が現れる傾向がある. 計算結果もこれと大きく矛盾せず, 現 れる結晶構造と計算結果から求めた最安定構造の対応は $75 \%$ であった．この中で B2 構造の対応が際立ってよいのに 対し, 実験的には B19 構造が現れる合金で $\mathrm{L} 1_{0}$ 構造が安定 であるという計算結果が得られているものが比較的多い。こ こで用いている計算手法 ASW 法は結晶格子が異方的な構造 を持つような系には精度の高い結果が得られないが，その影 響が $\mathrm{L} 1_{0}$ 構造よりも $\mathrm{B} 19$ 構造の生成エンタルピー計算に顕 著に現れ，相対的に B19 構造が不安定であると評価されて いるものと考えられる.

Fig. 3 に示したように, ホイスラー類似構造の対角線に沿 った原子配列を(1) $\mathrm{Co}-\mathrm{Fe}-\mathrm{Ti}-\mathrm{Zr} ，(2) \mathrm{Co}-\mathrm{Fe}-\mathrm{Zr}-\mathrm{Ti} ，(3) \mathrm{Co}-$ $\mathrm{Zr}-\mathrm{Fe}-\mathrm{Ti}$ の三通りにとり，それらの安定性を求めた。 その 結果を Fig. 9 に示す.これより，(1)と(2)の構造に関するエ ネルギー曲線はほぼ一致することがわかる．これらと比べて (3)の曲線はより大きな平均原子間距離においてより低いエネ ルギーをとり，前二者と比べて安定である. Fig. 10 には, 生成エンタルピーの最低值を比較するため, CoTi-CoZr$\mathrm{FeZr}-\mathrm{FeTi}$ 断面に二元系 B2 構造と $\mathrm{Co}-\mathrm{Ti}-\mathrm{Fe}-\mathrm{Zr}$ ホイス ラー類似構造の生成エンタルピーを示した. $\mathrm{Co}-\mathrm{Ti}-\mathrm{Fe}-\mathrm{Zr}$ ホイスラー類似構造の生成エンタルピーは周囲の B2 構造の 生成エンタルピーの平均值 (OAverage で表記) と比べて高 い.さらにこれらは B2-FeTi と B2-CoZr の二相分離を仮定 しだ印と比較するとかなり高い值であり, ホイスラー類似 構造, B2 連続固溶体いずれも安定ではないと考えられる. なお，これらの計算には市販のパソコンを用い，計算時間は $\mathrm{Co}-\mathrm{Ti}-\mathrm{Fe}-\mathrm{Zr}$ ホイスラー類似構造に関しては 2 日程度, 99 の二元系化合物合金に関しては総計で 10 日程度であった.

\section{Co-Fe-Ti-Zr 四元系合金の実験結果および考察}

$\mathrm{Co}-\mathrm{Ti}-\mathrm{Fe}-\mathrm{Zr}$ ホイスラー構造の存在の可否については計 算結果と比較できる知見が見当たらないため, ここでは実験 的な確認を試みた。Fig. 11 には熱処理を施した合金のミク ロ組織を示す. Alloy 1 で大きな体積分率を占める灰色の相 は, WDS 分析により $21.3 \mathrm{Co}-27.5 \mathrm{Fe}-24.3 \mathrm{Ti}-26.9 \mathrm{Zr}$ (at.\%) の組成を持ち, Alloy 2 で大きな体積分率を占める灰色の相 とほぼ同じ組成を持つことが明らかとなった。この組成は $(\mathrm{Co}+\mathrm{Fe})$ が 50 at.\%よりやや少ないが，その $\mathrm{Zr}-\mathrm{Ti}$ 比之 $\mathrm{Fe}-\mathrm{Co}$ 比を $\mathrm{CoTi}-\mathrm{CoZr}-\mathrm{FeZr}-\mathrm{FeTi}$ 断面に示したものが Fig. 12 である.ややFeZr 方向にずれているが, 図のほぼ 中央に位置する.二つの合金の X 線回折パターンを Fig. 13 (a)に示す。共通した多数のピークはこの相のものであ る.これらは Fig. 13 (b) に示す準安定 $\mathrm{C} 14-\mathrm{Fe}_{2} \mathrm{Zr}$ の回折パ ターンによく一致しており, bcc を基本とする構造ではない と結論できる．この実験例から，4元素の等組成合金であっ ても $\mathrm{B} 2$ 構造や $\mathrm{L} 1_{0}$ 構造のような $\mathrm{AB}$-type の化合物や, $\mathrm{D} 0_{19}$ 構造や $\mathrm{L}_{2}$ 構造のような $\mathrm{A}_{3} \mathrm{~B}$-type の化合物以外の化 合物単体が現れる可能性が排除できないことがわかる. 上記 の $\mathrm{B} 2$ 構造や $\mathrm{D} 0_{19}$ 構造のような化合物やその固溶体, さら にはそれらの化合物を基本としてさらに規則化した化合物は, 
(a)

\begin{tabular}{|c|c|c|c|c|c|c|c|c|c|c|c|c|}
\hline$A B$ & & $\mathrm{Zr}$ & $\mathrm{Hf}$ & $\mathrm{Ti}$ & $\mathrm{Ta}$ & $\mathrm{Nb}$ & V & W & Mo & $\mathrm{Cr}$ & $\mathrm{Re}$ & $\mathrm{Mn}$ \\
\hline & & 49 & 50 & 51 & 52 & 53 & 54 & 55 & 56 & 57 & 58 & 60 \\
\hline $\mathrm{Fe}$ & 61 & B2 & B2 & B2 & B2 & (B2) & B2 & (L10) & (L10) & (L10) & B19 & B19 \\
\hline $\mathrm{Ru}$ & 62 & B2 & B2 & B2 & B2 & B2 & B2 & (L10) & (B19) & (B19) & (B19) & (B19) \\
\hline Os & 63 & B2 & B2 & B2 & B2 & (B2) & B2 & (B19) & (B19) & (B19) & B19 & (B19) \\
\hline Co & 64 & B2 & B2 & B2 & L10 & L10 & L10 & L10 & L10 & L10 & B19 & B19 \\
\hline $\mathrm{Rh}$ & 65 & B2 & B2 & B2 & L10 & L10 & L10 & L10 & B19 & B19 & B19 & B19 \\
\hline Ir & 66 & B2 & B2 & B2 & L10 & L10 & L10 & B19 & B19 & B19 & B19 & B19 \\
\hline $\mathrm{Ni}$ & 67 & B19 & B19 & L10 & L10 & L10 & L10 & B19 & B19 & (B19) & B19 & (B19) \\
\hline $\mathrm{Pt}$ & 68 & B19 & $O A 1 \mathrm{~A}$ & L10 & L10 & L10 & L10 & B19 & B19 & B19 & (B19) & (L10) \\
\hline $\mathrm{Pd}$ & 69 & L10 & L10 & L10 & L10 & L10 & L10 & (B19) & (B19) & (B19) & (B19) & (L10) \\
\hline
\end{tabular}

(b)

\begin{tabular}{|c|c|c|c|c|c|c|c|c|c|c|c|c|}
\hline$A B$ & & $\mathrm{Zr}$ & $\mathrm{Hf}$ & $\mathrm{Ti}$ & $\mathrm{Ta}$ & $\mathrm{Nb}$ & V & W & Mo & $\mathrm{Cr}$ & $\mathrm{Re}$ & $\mathrm{Mn}$ \\
\hline & & 49 & 50 & 51 & 52 & 53 & 54 & 55 & 56 & 57 & 58 & 60 \\
\hline $\mathrm{Fe}$ & 61 & & & B2 & & & B2 & & & & & \\
\hline $\mathrm{Ru}$ & 62 & B2 & B2 & & $\begin{array}{l}\text { B2+ } \\
\text { L10 }\end{array}$ & $\begin{array}{l}\text { B2+ } \\
\text { L10 }\end{array}$ & B2 & & & & & \\
\hline Os & 63 & B2 & B2 & B2 & & & B2 & & & & & \\
\hline Co & 64 & B2 & B2 & B2 & & & & & & & & \\
\hline $\mathrm{Rh}$ & 65 & B2 & B2 & $\begin{array}{l}\text { B2+ } \\
\text { L10 }\end{array}$ & & $\begin{array}{c}\text { L10+ } \\
\text { B19 }\end{array}$ & L10 & & B19 & & & B2 \\
\hline Ir & 66 & B2 & B2 & $\begin{array}{l}\text { B2+ } \\
\text { L10 }\end{array}$ & & L10 & L10 & B19 & B19 & & & $\begin{array}{l}\text { B2+ } \\
\text { L10 }\end{array}$ \\
\hline $\mathrm{Ni}$ & 67 & & & $\begin{array}{l}\text { B2+ } \\
\text { B19 }\end{array}$ & & & & & & & & $\begin{array}{l}\text { B2+ } \\
\text { B19 }\end{array}$ \\
\hline $\mathrm{Pt}$ & 68 & B2 & B2 & $\begin{array}{l}\text { B2+ } \\
\text { B19 }\end{array}$ & & B19 & B19 & & B19 & L10 & & L10 \\
\hline $\mathrm{Pd}$ & 69 & & & $\begin{array}{l}\text { B2+ } \\
\text { B19 }\end{array}$ & & & & & & L10 & & $\begin{array}{l}\text { B2+ } \\
\text { L10 }\end{array}$ \\
\hline
\end{tabular}

Fig. 8 (a) The most stable structure determined by the first principles calculation. (b) A part of Pettifor map for binary AB alloys.

ASW 計算の範疇で相対的な安定性の評価を試みることが可 能であると期待される。一方， $\mathrm{A}_{2} \mathrm{~B}$-type である Laves 相 $\mathrm{C} 14$ 構造などは $\mathrm{B} 2$ 構造や $\mathrm{L} 1_{0}$ 構造と比較して対称性の低い 複雑な原子配置を有するため，その固溶体合金であると予想 される本相の形成エネルギーは本研究で用いた ASW 法では 十分取り扱えず， あくまで電子論的立場から安定性を議論す るためには FLAPW 法などのより近似度の高い手法を用い ることが必要であると考えられる。しかし，高速性を重要視 した計算による相の存在可能性の判断手法確立の観点という 本研究の目的からすると, $\mathrm{C} 14$ 構造の出現は, 本合金系で ホイスラー類似相が $\mathrm{B} 2$ 連続固溶体や B2-B2 二相分離と比
べてさえ不安定で出現し得ないと判断した計算結果と矛盾す るものではない，安定相としての出現を，競合相間の生成工 ンタルピーの比較ではなく, 着目した化合物の生成エンタル ピーの大きさから判断することが可能かどうか，計算結果も 踏まえて以下で検討する.

Fig. 14 に，本計算結果に打ける各化合物の生成エンタル ピーを示す．ここでは対象として実験に用いた合金の構成元 素である $\mathrm{Co}$ もしくは Fe を含む組反合わせ 22 通りを示した。

Fig. 8(b) からも判る通り，この組反合わせ範囲内で形成さ れる化合物は B2 構造を有する 5 つしかない，仮に，生成工 ンタルピー $-0.4 \mathrm{eV} /$ atom を境界と仮定し，これ以上大きな 

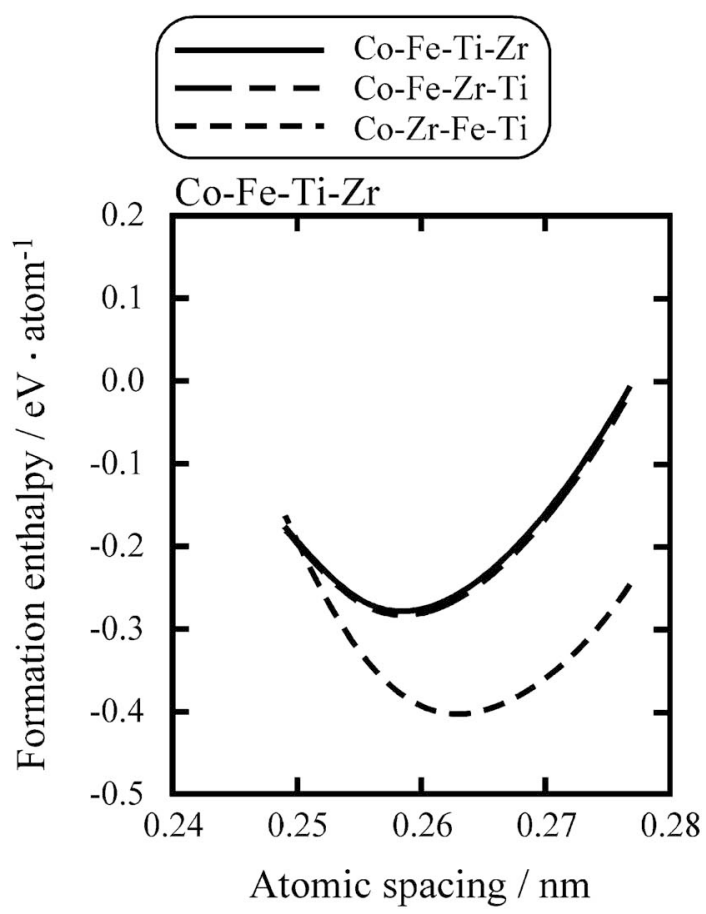

Fig. 9 Results of ASW calculations for $\mathrm{Co}-\mathrm{Fe}-\mathrm{Ti}-\mathrm{Zr}$ Heuslerlike compounds with different atomic arrangement.

生成エンタルピーを持つ場合は不安定で出現しないとしてそ の仮定の当否を検討すると， Co もしくは $\mathrm{Fe}$ を含む組み合 わせ 22 例のうち 21 例はこの条件で出現の有無を説明でき ることになる。また，ASW 計算を行った全 99 通りについ て同じ判定を行ったところ，およそ $75 \%$ が出現の有無を正 しく判定できた．本実験で出現しなかった四元系ホイスラー 類似構造の生成エンタルピーはこの境界上にあり, 安定性は 十分に高くないことになる。このことから，本実験も，化合 物相のスクリーニングのための安定性評価法にひとつの例を 与えるものと評価できる. 今後は, Laves 相 C14 構造の FLAPW 法による生成エンタルピー計算なども視野に入れ つつ, 四元系ホイスラー相が報告されている系を中心とし て, 比較的単純な結晶構造を持つ化合物の出現傾向 ·安定的 評価を，高速な ASW 法による計算結果から経験的に行うた めの実験との対応関係をさらに積み上げていくことが必要で あると考える。

\section{6. 結言}

実験的な化合物探索のためのスクリーニングに焦点を絞っ た高速な電子論計算を行い，実験的に求めた二元系抢よび四 元系化合物との対応関係を調查した

対象とした 99 の $1: 1$ 二元系化合物では, この領域内で 実験的研究により報告されている $\mathrm{B} 2, \mathrm{~L} 10, \mathrm{~B} 19$ 各構造の約 $75 \%$ が計算結果と一致した。 $\mathrm{L} 1_{0}$ 構造や B19 構造のように 結晶格子が異方的な構造を持つ系では, 計算される生成エン タルピーへの影響が構造によって異なることが明らかとなっ た. $\mathrm{Co}_{0}-\mathrm{Fe}-\mathrm{Ti}-\mathrm{Zr}$ 四元系化合物の計算結果から，仮定した ホイスラー類似構造は安定ではないと結論した。実験より, (a)

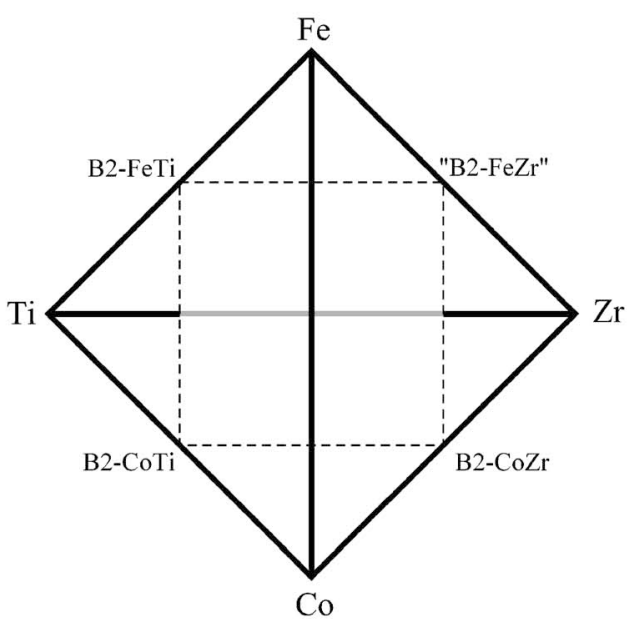

(b)

$\mathrm{B} 2-\mathrm{FeTi}$ "B2-FeZr" $-0.479 \mathrm{eV} \cdot$ atom $^{-1} \quad-0.331 \mathrm{eV} \cdot$ atom $^{-1}$

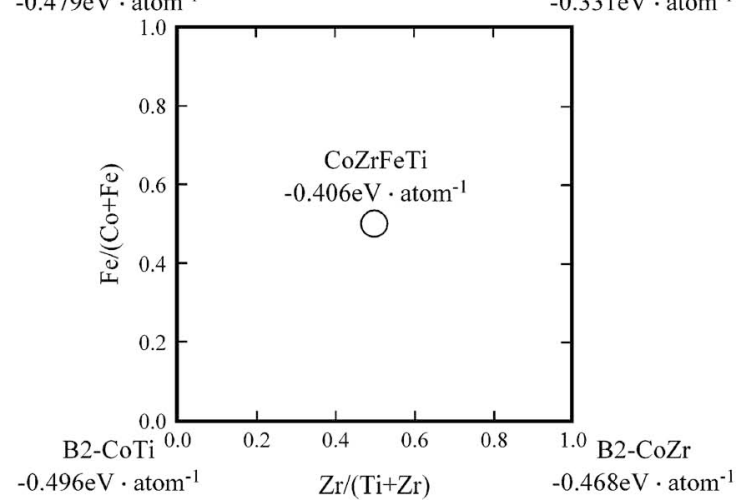

(c)

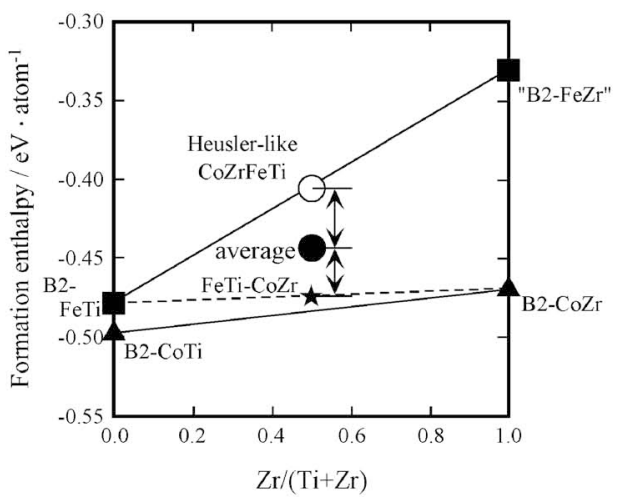

Fig. 10 Comparison of the formation enthalpy within $\mathrm{CoTi}^{-}$ CoZr-FeZr-FeTi section of Co-Fe-Ti-Zr quaternary system.

この組成領域では Laves 相 $\mathrm{C} 14$ 構造 $\mathrm{Fe}_{2} \mathrm{Zr}$ 固溶体が確認さ れた．このことは，生成エンタルピーから相の出現傾向を判 断する上で一つの例証となるものと考えられ，結晶構造の対 称性が高いなど, 本研究で用いた計算手法にとって有利な, 適切な探查対象に対しては電子論計算の精度と実験的な手法 を高い程度でバランスさせた広域組成領域での化合物探査へ の可能性が見出された. 
Alloy 1 heat-treated at $900{ }^{\circ} \mathrm{C}$ for $96 \mathrm{~h}$
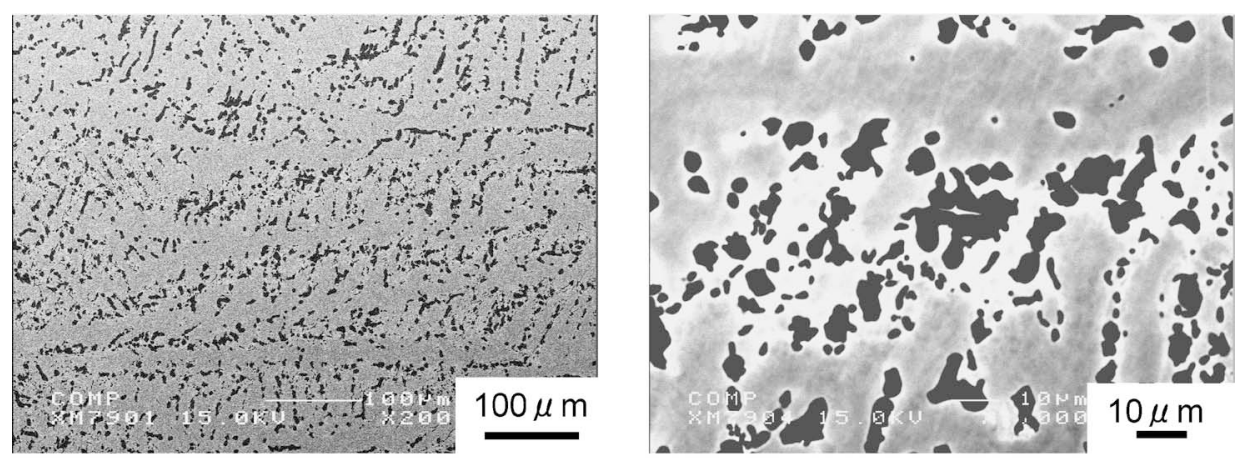

Alloy 2 heat-treated at $900^{\circ} \mathrm{C}$ for $96 \mathrm{~h}$
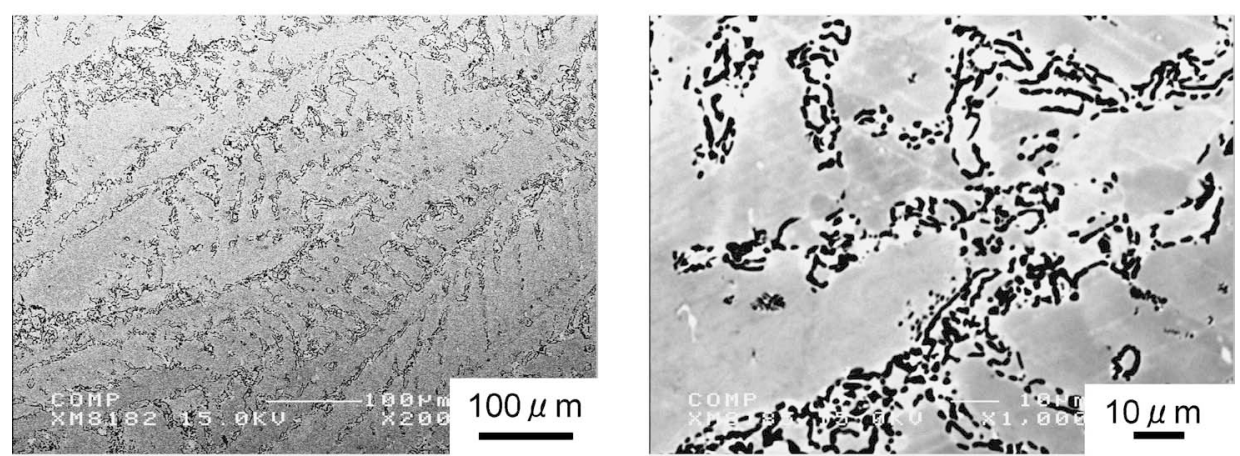

Fig. 11 Results of microstructure observation of $\mathrm{Co}-\mathrm{Fe}-\mathrm{Ti}-\mathrm{Zr}$ quaternary alloys heat-treated at $900^{\circ} \mathrm{C}$ for $96 \mathrm{~h}$.

B2-FeTi

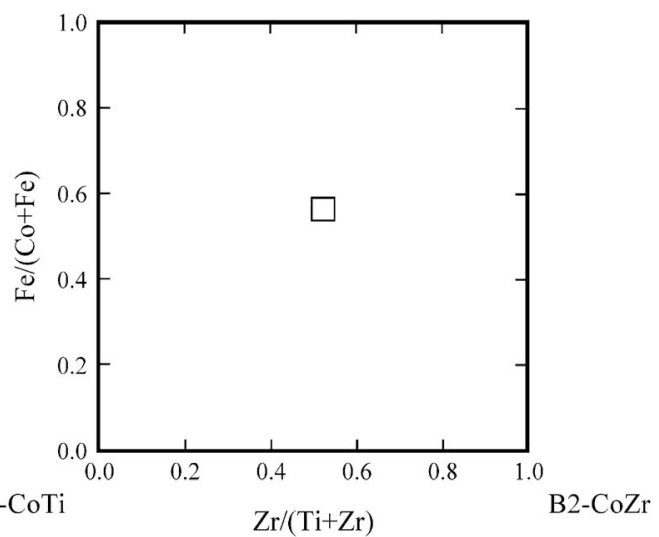

Fig. 12 Composition of a phase observed in $\mathrm{Co}-\mathrm{Fe}-\mathrm{Ti}-\mathrm{Zr}$ quaternary alloys. (a)

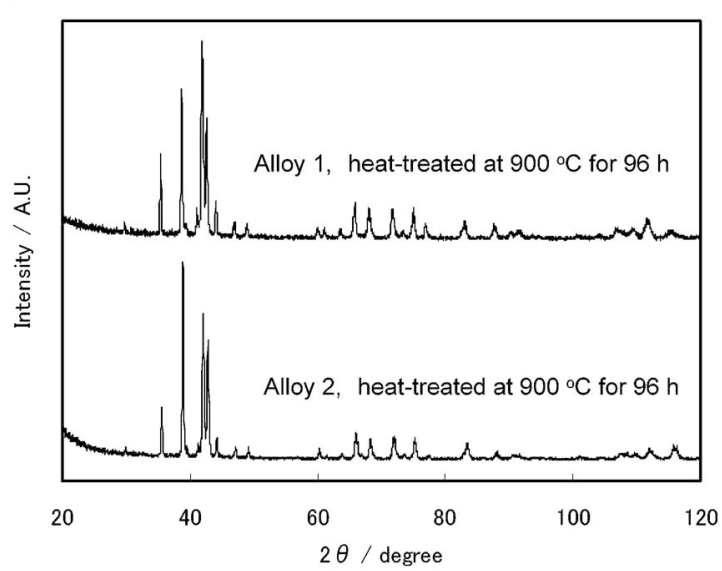

(b) $\mathrm{Fe}_{2} \mathrm{Zr}(\mathrm{hP} 24,26-809)$

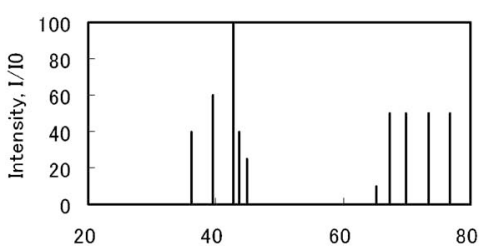

Fig. 13 (a) Results of the X-ray diffractometry of $\mathrm{Co}^{-}-\mathrm{Fe}-\mathrm{Ti}-$ $\mathrm{Zr}$ quaternary alloys. (b) XRD pattern of $\mathrm{C} 14-\mathrm{Fe}_{2} \mathrm{Zr}$. 


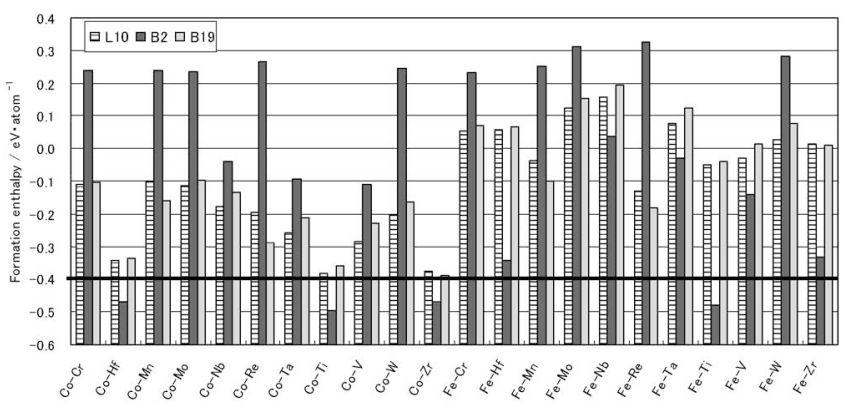

Fig. 14 Results of ASW calculations for $\mathrm{Co}^{-} \mathrm{X}$ and $\mathrm{Fe}-\mathrm{X}$ compounds.

文

\section{献}

1) S. Ochiai, Y. Oya and T. Suzuki: Acta Met. 32(1984) 289-298.

2) C. T. Liu: International Metals Reviews 29 (1984) 168-194.

3) S. Kawatsu, Y. Oya and T. Suzuki: Trans. ISIJ 21(1981) B336.

4) S. Miura, H. Kuriyama, Y. Mishima and T. Suzuki: J. Japan Inst. Metals 56(1992) 943-951.

5) S. Hasegawa, S. Wada, T. Takasugi and O. Izumi: Mat. Res. Soc. Symp. Proc., 288 (1993) 659-663.

6) J. Sato, T. Omori, K. Oikawa, I. Ohnuma, R. Kainuma and K. Ishida: SCIENCE 312(2006) 90-91.

7) D. Weller, A. Moser, L. Folks, M. E. Best, W. Lee, M. F. Toney, M. Schwickert, J. U. Thiele and M. F. Doerner: IEEE Trans. Magn. 36(2000) 10-15.

8) Y. Yamabe-Mitarai, T. Hara, S. Miura and H. Hosoda: Mat. Trans. 47 (2006) 650-657.

9) D. G. Pettifor, "The Science of alloys for the $21^{\text {st }}$ century: Hume-Rothery symposium Celebration” , ed. by P.A.E.Turchi, R. D. Shill and A. Gonis, TMS, Warrendale, 2000, p. 9-32.
10) Japan Society for the Promotion of Science 156 committee, "Zairyou System Gaku”, KYORITSU SHUPPAN CO., LTD, Tokyo, (1997), p. 324-344.

11) T. Mohri and Y Chen: Mat. Trans. 43 (2002) 2104-2109.

12) G. H. Bozzolo, R. D. Noebe and C. Amador: Intermetallics 10 (2002) 149-159.

13) J. C. Zhao, M. R. Jackson and L. A. Peluso: Mat. Sci. Eng., A $372(2004)$ 21-27.

14) A. van de Walls and G. Ceder: J. Phase Equilibria 23(2002) 348-359.

15) P. Villars, K. Brandenburg, M. Berndt, S. LeClair, A. Jackson, Y.-H. Pao, B. Igelnik, M. Oxley, B. Bakshi, P. Chen and S. Iwata: J. Alloys and Compounds 317-318(2001) 26-38.

16) P. Villars, K. Cenzual, J. Daams, Y. Chen and S. Iwata: J. Alloys and Compounds 367 (2004) $167-175$.

17) P. Hohenberg and W. Kohn: Phys. Rev. 136(1964) B864.

18) W. Kohn and L. J. Sham: Phys. Rev. 140 (1965) A1133.

19) A. R. Williams, J. Kübler and C. D. Gelatt, Jr.: Phys. Rev. B 19 (1979) 6094.

20) V. L. Moruzzi, J. F. Janak and A. R. Williams: Calculated Electronic Properties of Metals, (Pergamon, New York, 1978).

21) D. D. Koelling and B. N. Harmon: J. Phys. C10(1977) 3107.

22) D. G. Pettifor: Intermetallic Compounds: Principles and Practice, ed. by J. H. Weatbrook and R. L. Fleischer, Vol. 1 (John Wiley and Sons Ltd, Baffin Lane, England, 1995), p. 425.

23) H. Okamoto: Desk Handbook Phase Diagram for Binary Alloys, (ASM International, Materials park, OH, 2000).

24) T. Takasugi, O. Izumi and M. Yoshida: J. Mat. Sci. 26(1991) 2941-2948.

25) O. A. Bannykh, K. Enami, S. Nagasaki and A. Nishiwaki: Tetsugoukin Joutaizushu, Agne gijutsu center, Tokyo, 2001.

26) N. Novaković, N. Ivanović, V. Koteski, I. Radisavljević, J. Belošević-Čavor and B. Cekić: Intermetallics 14(2006) 14031410.

27) Qiti Guo and O. J. Kleppa: J. Alloys Comp. 321 (2001) 169-182.

28) P. Villars and L. D. Calvert: Pearson's Handbook of Crystallographic Data for Intermetallic Phases, (ASM, Materials park, $\mathrm{OH}, 1985)$.

29) Y. Terada, K. Ohkubo, T. Mohri T and T. Suzuki: Mater. Trans. 43(2002) 3167-3176. 